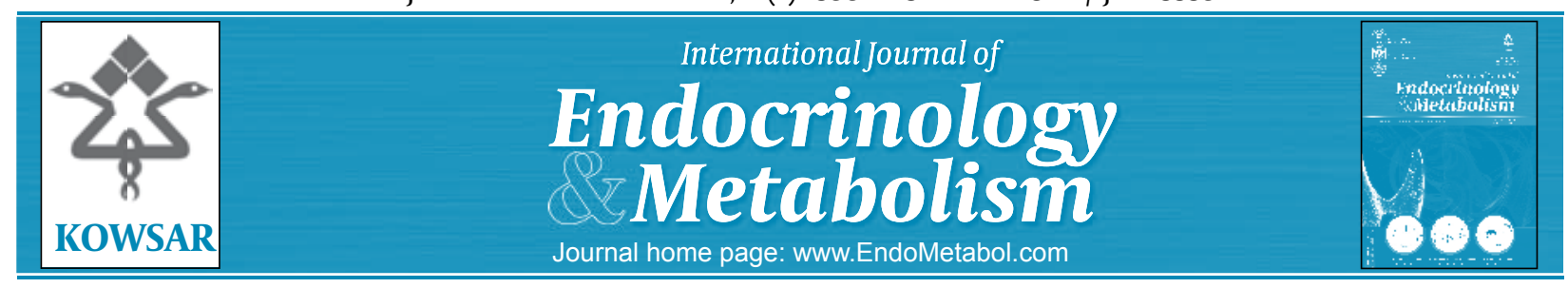

\title{
Changes in Cytokines, Biomarkers of Bone Turnover and Hormones Are Associated With Bone Loss in Postmenopausal Indian Women
}

\author{
Meena Desai ${ }^{1 *}$, Mohammed Ikram Khatkhatay ${ }^{1}$, Vijaya Taskar ${ }^{2}$, Zakiya Ansari ${ }^{1}$ \\ ${ }^{1}$ Department Molecular Immunodiagnostics, University of Mumbai, Mumbai, India National Institute for Research in Reproductive Health, Mumbai, India \\ ${ }^{2}$ Streehitakarini Clinic, Mumbai, India
}

A R T I C L E I N F O

Article type:

Original Article

Article history:

Received: 31 Oct 2011

Revised: 01 Jan 2012

Accepted: 20 Jan 2012

Keywords:

Cytokines

Estrogens

Postmenopausal Osteoporosis

\begin{abstract}
A B S T R A C T
Background: The pro-inflammatory cytokines that are associated with the decline in ovarian function during menopause are involved in the pathophysiology of postmenopausal bone loss, which has not been examined in Indian postmenopausal women. Objectives: This study assessed the extent of changes in pro-inflammatory cytokines in relation to bone turnover markers, hormones, and bone mineral density (BMD) during menopausal transition in Indian women.

Materials and Methods: Levels of interleukin 1(IL1 $\beta$ ), interleukin 6 (IL6), and tumor necrosis factor (TNF $\alpha)$; the bone markers osteocalcin (OC), bone-specific alkaline phosphatase (BSAP), carboxy terminal telopeptide (CTX), and deoxypyridoniline (DPD); and the hormones parathyroid hormone (PTH), follicle-stimulating hormone (FSH), and estrone glucuronide (E1G) were measured by enzyme linked immunosorbant assay (ELISA) in blood and urine samples of premenopausal (age: 21-40 years, $n=124$ ) and menopausal women (41-70 years, $n=256$ ) without fractures. Bone mineral density (BMD) in the femur and spine was measured by dual energy x-ray absorptiometry (DXA).

Results: Of the cytokines that were measured, only IL6 increased significantly in all 3 groups of menopausal women (compared with premenopausal healthy women. The changes in IL6 paralleled changes in markers of bone resorption and correlated positively with bone turnover markers and negatively with BMD and E1G levels. In menopausal women, the rise in IL6, CTX, and DPD was high ( $>100 \%)$ and was associated with a decline in $\mathrm{E} 1 \mathrm{G}(>75 \%)$ and BMD levels ( $>22 \%$ ) during the first 5 years of menopause, indicating that bone loss is confined to the first decade of menopause.

Conclusions: IL6 correlates negatively with estrogens and BMD and positively with bone resorption markers. Thus, IL6 levels, in conjunction with CTX, DPD, and estrogen levels, improve the prediction of bone loss in menopausal women.
\end{abstract}

Copyright @ 2012 Kowsar M.P. Co. All rights reserved.

- Implication for health policy/practice/research/medical education:

The article will be help Clinicians in predicting and planning correct strategies for postmenopausal bone loss.

- Please cite this paper as:

Desai M, Khatkhatay MI, Taskar V, Ansari Z. Changes in Cytokines, Biomarkers of Bone Turnover and Hormones Are Associated With Bone Loss in Postmenopausal Indian Women. Int J Endrocrinol Metab. 2012:10(1):399-403. DOI: 10.5812/ijem.3339

* Corresponding author: Meena Desai, Department Molecular Immunodiagnostics, National Institute for Research in Reproductive Health, Mumbai, India, Jehangir Merwanji Street, Parel, Mumbai, India. Tel: +91-2224192026, Fax:+91-2224139412, E-mail: mends153@gmail.com

DOI:10.5812/ijem.3339

Copyright @2012 Kowsar M. P. Co. All rights reserved.

\section{Background}

The human immune system is influenced by changes in the endocrine system. Hormonal changes, such as declines in estrogen and elevated gonadotropins, modulate the immune regulatory system during the menopausal transition. Cytokines, the key regulators of the immune responses, are crucially involved in 
neuroendocrine immune interactions, whereas estrogen appears to regulate immune function (1-3). Natural menopause is associated with a rapid decline in circulating estrogen; conversely, changes in cytokines during menopausal transition are involved in the pathogenesis, development, and progression of postmenopausal osteoporosis and atherosclerosis. The pro-inflammatory cytokines IL1 $\beta$, IL6, and TNF $\alpha$, which are associated with the decline in ovarian function in menopause, have been shown to act as bone-resorbing cytokines (4-6).

Due to the increase in the average life expectancy, women spend more than one-third of their lifetime in menopause, and the implications of estrogen deficiency in the rates of cardiovascular diseases and osteoporosis have tremendous significance to public health. Thus, it is essential to investigate the changes in cytokine levels in women during menopausal transition.

\section{Objectives}

The aim of this cross-sectional study was to examine the relationship of circulating levels of pro-inflammatory cytokines, bone turnover markers, and hormones to bone mineral density during menopausal transition in Indian women to identify who is at risk for osteoporosis.

\section{Materials and Methods}

\subsection{Subjects}

The institutional ethics committee approved the research protocols. The study group comprised 380 women between the ages of 21 and 70 years $(n=124$, ages 21-40 years as premenopausal; and $n=256,41-$ 70 years as menopausal) who were enrolled at the Institute and Streehitakarini Clinic Mumbai, a community-based clinic approximately $2 \mathrm{~km}$ from the institute. The method of recruitment was prospective, by motivation or through awareness of osteoporosis, and targeted women from the middle socioeconomic group of a large urban population. Most women from this group were literate housewives; some were employed and generally consumed an adequate, well-balanced diet. Their routines and detailed clinical and obstetric histories were recorded, and women who had a history of fractures, any endocrinological problem or illness, or consumed bonecompromising drugs were excluded from the study. Thus, the study participants were apparently healthy and active, having sufficient exposure to sunlight, as evident from their routines. The enrolled subjects underwent simultaneous BMD (expressed as $\mathrm{g} / \mathrm{cm} 2$ ) of the lumbar spine (L1-L4) and hip (femur neck) by dual X-ray absorptiometry (DXA, QRR 1000, Hologic Inc. USA) by an expert radiologist.

\subsection{Methodology}

Venous blood samples and first morning urine specimens were obtained. A single blood sample (10 AM - 11 AM) and a first morning urine specimen was obtained from menopausal women on any convenient day, whereas samples were collected between Days 5-7 of the cycle from premenopausal women. Both urine and serum specimens were stored at $-20^{\circ} \mathrm{C}$ till analyzed. Serum calcium (Ca) and phosphorous (P) were measured by standard methods $(7,8)$, whereas hormonal profiles were assessed by measuring urinary estrone glucuronide (E1G), a principal metabolite of estradiol in urine, and FSH by in-house $\operatorname{ELISA}(9,10)$. The bone turnover markers osteocalcin (OC), bone-specific alkaline phosphatase (BSAP), carboxy terminal telopeptide (CTX), collagen crosslinks deoxypyridinoline (DPD), and parathyroid hormone were measured using commercial kits (Diagnostics System Lab, USA). Urinary measurements were expressed as concentration of the analyte per mg creatinine content of the sample, with creatinine estimated by Jaffe reaction (11). The cytokines IL1 $\beta$, IL6, and TNF $\alpha$ were measured using Opt EIA reagents (BD Pharmingen Co. USA). In-house sandwich ELISAs for cytokines were standardized using specific antisera and streptavidin-enzyme conjugate. The intra- and interassay coefficients of variation were less than $10 \%$ and $15 \%$, respectively.

\subsection{Data Analysis}

The participants were assigned to group I, comprising healthy women with normal menstrual cycles and normal bone mass, and group II, comprising menopausal women above the age of 40 years, having either irregular cycles or no menses. Group II $(n=256)$ was further classified, based on BMD, as normal with normal bone mass $(n=40)$, with osteopenia $(n=83)$, or with osteoporosis $(n=133)$ per WHO classification (normal values $<-1.0$ to 2.5 and osteoporotic $\mathrm{T}$ value $>-2.5$ (12). Postmenopausal women were also subgrouped by years since menopause (YSM) : > 1-5 YSM, > 5-10 YSM, and $>10$ YSM.

All statistical analyses were performed using Graph Pad prism, version 5.0 (Graph Pad software, Inc). The data were expressed as mean \pm SD and 95\% confidence intervals (CIs), with statistical significance defined by the $P$ value. Differences in mean levels of hormones, cytokines, and bone markers were compared by nonparametric student $t$ test to assess their level of significance.

\section{Results}

The BMI of premenopausal women differed significantly from that of menopausal women $(22.1 \pm 2 \mathrm{vs}$. $\left.25.1 \pm 2.1 \mathrm{~kg} / \mathrm{m}^{2} ; P<0.001\right)$. To assess the changes in cy- 
tokines, bone turnover markers, and hormones during menopause, group II women were segregated based on BMD-14\% of menopausal women had normal BMD, 22\% had osteopenia, and $64 \%$ had osteoporosis. The anthropometric measurements of the premenopausal and menopausal women are shown in Table 1. The cutoffs of bone markers and hormones that were established by our laboratory were used for comparison $(13,14)$. The $\mathrm{Ca}$ and $\mathrm{P}$ levels in menopausal women were toward the lower end of the normal range compared with premenopausal women. The BMD measurements in spine and femur were also significantly lower $(P<0.001)$ ver- sus menopausal women with normal BMD. The levels of cytokines, bone turnover markers, and hormones in menopausal women are shown in Table 2. Elevated levels of TNF $\alpha$ and IL6 were associated with low BMD in the spine and hip in menopausal women versus premenopausal women with low bone mass. Elevated levels of TNF $\alpha$ and IL6 also correlated well with increases in the bone resorption markers CTX and DPD and concurrent low levels of E1G. Because IL6 levels showed a maximum $73.7 \%$ rise $(13.2 \pm 2.26 \mathrm{ng} / \mathrm{mL}, P<0.0001)$ versus other cytokines, it appeared to be a potent stimulator of bone loss.

\begin{tabular}{|c|c|c|c|c|c|c|}
\hline & \multicolumn{2}{|c|}{$\begin{array}{l}\text { Premenopausal Women } \\
\qquad(\mathrm{n}=124)\end{array}$} & \multicolumn{3}{|c|}{ Menopausal Women $(\mathrm{n}=\mathbf{2 5 6})$} & \multirow[t]{2}{*}{ Pvalue } \\
\hline & $\begin{array}{l}\text { Normal } \\
(\mathrm{n}=98)\end{array}$ & $\begin{array}{l}\text { Osteopenia } \\
(\mathrm{n}=26)\end{array}$ & $\begin{array}{l}\text { Normal } \\
(n=40)\end{array}$ & $\begin{array}{l}\text { Osteopenic } \\
(\mathrm{n}=83)\end{array}$ & $\begin{array}{l}\text { Osteoporotic } \\
(\mathrm{n}=133)\end{array}$ & \\
\hline Age, y, Mean \pm SD & $29.3 \pm 5.20$ & $32.8 \pm 4.80$ & $45.2 \pm 4.60$ & $47.1 \pm 5.20$ & $51.6 \pm 5.20$ & - \\
\hline BMI, $\mathrm{kg} / \mathrm{m}^{2}$, Mean $\pm \mathrm{SD}$ & $22.1 \pm 2.10$ & $22.7 \pm 2.40$ & $25.1 \pm 2.10$ & $25.9 \pm 2.40$ & $26.2 \pm 2.80$ & - \\
\hline \multicolumn{7}{|l|}{$\mathrm{BMD}, \mathrm{g} / \mathrm{cm}^{2}$} \\
\hline Spine & $1.128 \pm 0.16$ & $1.096 \pm 0.13$ & $1.081 \pm 0.14^{\mathrm{a}}$ & $0.976 \pm 0.13^{b}$ & $0.899 \pm 0.11^{c}$ & (a vs.b, bvs.c), $P<0.001$ \\
\hline Femur & $0.999 \pm 0.11$ & $0.983 \pm 0.98$ & $0.908 \pm 0.11^{d}$ & $0.804 \pm 0.12^{\mathrm{e}}$ & $0.769 \pm 0.12$ & $(\mathrm{~d} v s . \mathrm{e}), P<0.001$ \\
\hline Calcium, mg/mL, Mean \pm SD & $9.22 \pm 0.98$ & $9.22 \pm 0.98$ & $8.8 \pm 0.98$ & $8.52 \pm 0.80$ & $8.10 \pm 0.75$ & - \\
\hline $\begin{array}{l}\text { Phosphorous, mg/mL, } \\
\text { Mean } \pm \text { SD }\end{array}$ & $5.23 \pm 0.73$ & $5.23 \pm 0.73$ & $4.73 \pm 0.93$ & $4.68 \pm 0.87$ & $4.44 \pm 0.58$ & - \\
\hline
\end{tabular}

${ }^{\mathrm{a}}$ Normal menopausal women $v$ s osteopenic menopausal women

To examine the value of serum IL6 as a predictor of bone loss, we categorized postmenopausal women according to years since menopause (YSM). The levels of IL1 $\beta$, IL6, TNF $\alpha$, bone markers, and hormones in these women are shown in Table 3. Serum IL6 levels in menopausal women were significantly elevated (13.62 $\mathrm{ng} / \mathrm{mL}: P<.0 .001)$ versus premenopausal women. IL6 levels also increased with years since menopause ( < $5 \mathrm{YSM},>5 \mathrm{YSM}$, and > 10 YSM), but the levels were no longer significant in women with more than 10 years after menopause. Among women with $>5$ YSM and $<$ 5 YSM, serum IL6 was the most important predictor of femoral bone loss, accounting for $21.7 \%$ of the variability in femoral BMD. Only 2 cytokines, TNF $\alpha$ and IL6, were significantly elevated in postmenopausal women versus premenopausal women, with rises of $30 \%$ and $102 \%$, respectively, and a rapid decline in E1G (70\%), resulting in bone loss.

\begin{tabular}{|c|c|c|c|c|c|c|}
\hline & \multicolumn{2}{|c|}{ Group I Premenopausal } & \multicolumn{3}{|c|}{ Group II Menopausal } & \multirow[t]{2}{*}{ P value } \\
\hline & $\begin{array}{l}\text { Normal } \\
(\mathrm{n}=98)\end{array}$ & $\begin{array}{l}\text { Osteopenic } \\
(n=26)\end{array}$ & $\begin{array}{l}\text { Normal } \\
(n=40)\end{array}$ & $\begin{array}{l}\text { Osteopenic } \\
(n=83)\end{array}$ & $\begin{array}{l}\text { Osteoporotic } \\
(n=133)\end{array}$ & \\
\hline IL1 $\beta, p g / m L$ & $4.82 \pm 1.9^{\mathrm{a}}$ & $4.72 \pm 1.5$ & $5.56 \pm 2.8$ & $6.23 \pm 2.6$ & $6.84 \pm 2.06$ & (a vs. b), $P<0.1$ \\
\hline IL $6, \mathrm{ng} / \mathrm{mL}$ & $7.24 \pm 2.0^{a}$ & $7.84 \pm 1.9$ & $9.87 \pm 2.5^{\mathrm{b}}$ & $11.05 \pm 2.89^{c}$ & $16.8 \pm 2.98^{\mathrm{d}}$ & (a vs. b, c, d) $P<0.001$ \\
\hline $\mathrm{TNF} \alpha, \mathrm{pg} / \mathrm{mL}$ & $4.69 \pm 1.8^{a}$ & $4.85 \pm 1.9$ & $5.08 \pm 2.7$ & $6.40 \pm 2.30$ & $7.92 \pm 2.98^{b}$ & (a vs. b) $P<0.001$ \\
\hline $\mathrm{OC}, \mathrm{ng} / \mathrm{mL}$ & $9.22 \pm 2.9$ & $9.09 \pm 2.6$ & $11.4 \pm 2.0$ & $12.02 \pm 1.96$ & $11.89 \pm 2.12$ & NS \\
\hline BSAP, IU/L & $15.89 \pm 4.6$ & $15.65 \pm 3.8$ & $16.2 \pm 3.8$ & $18.28 \pm 4.01$ & $19.29 \pm 3.63$ & NS \\
\hline CTX,$\mu / \mathrm{molCr}$ & $312 \pm 94.8^{a}$ & $326 \pm 100$ & $482 \pm 109.8^{b}$ & $612 \pm 102.3$ & $998 \pm 160.2^{d}$ & (a vs. b, c, d), $P<0.0001$ \\
\hline $\mathrm{DPD}$ nmol/molCr & $2.76 \pm 0.9^{a}$ & $2.89 \pm 0.8$ & $3.82 \pm 0.9$ & $5.34 \pm 1.02$ & $6.62 \pm 1.57^{c}$ & (a vs.b, c) $P<0.0001$ \\
\hline $\mathrm{FSH}, \mathrm{mIU} / \mathrm{mgCr}$ & $22.83 \pm 5.2^{\mathrm{a}}$ & $21.89 \pm 4.8$ & $40.86 \pm 6.5^{b}$ & $48.92 \pm 8.8^{c}$ & $56.63 \pm 9.2^{d}$ & (a vs.b, c, d) $P<0.0001$ \\
\hline $\mathrm{E} 1 \mathrm{G}, \mathrm{ng} / \mathrm{mgCr}$ & $48.96 \pm 8.9^{a}$ & $46.73 \pm 7.3$ & $26.86 \pm 5.6^{b}$ & $15.48 \pm 4.8^{b}$ & $8.9 \pm 2.7^{\mathrm{d}}$ & (a vs.b, c, d) $P<0.0001$ \\
\hline PTH, pg/mL & $26.73 \pm 3.8^{a}$ & $27.19 \pm 3.6$ & $36.3 \pm 4.2 b$ & $36.3 \pm 4.2^{b}$ & $39.6 \pm 4.4$ & (a vs.b) $P<0.001$ \\
\hline
\end{tabular}

NS, Not significant 


\begin{tabular}{|c|c|c|c|c|c|}
\hline \multirow[t]{2}{*}{ Analyte } & \multirow{2}{*}{$\begin{array}{l}\text { Premenopausal } \\
\text { with low }{ }^{\mathrm{b}} \text { one mass } \\
(\mathbf{n}=\mathbf{2 6})\end{array}$} & \multicolumn{3}{|c|}{ Postmenopausal women } & \multirow[t]{2}{*}{$P$ value } \\
\hline & & $<5$ YSM $(n=68)$ & $\begin{array}{l}>5 \text { YSM } \\
(\mathrm{n}=82)\end{array}$ & $\begin{array}{l}>10 \text { YSM } \\
(n=66)\end{array}$ & \\
\hline IL1 $\beta, p g / m L$ & $4.72 \pm 1.5^{\mathrm{a}}$ & $6.02 \pm 1.83(27.5 \%)$ & $5.99 \pm 1.69^{c}(26.9 \%)$ & $\begin{array}{l}6.03 \pm 1.65^{d} \\
(27.75 \%)\end{array}$ & $\mathrm{NS}^{*}$ \\
\hline IL $6, \mathrm{ng} / \mathrm{mL}$ & $7.84 \pm 1.9^{\mathrm{a}}$ & $13.62 \pm 2.26^{\mathrm{b}}(73.7 \%)$ & $\begin{array}{l}15.89 \pm 2.7^{c} \\
(102.6 \%)\end{array}$ & $\begin{array}{l}16.21 \pm 2.89^{d} \\
(106.76 \%)\end{array}$ & $\begin{array}{l}(\mathrm{a} v s . \mathrm{b}, \mathrm{b} v s . \mathrm{c}) \\
P<0.001 \\
\text { c } v s . \mathrm{d}=\mathrm{NS}\end{array}$ \\
\hline $\mathrm{TNF} \alpha, \mathrm{pg} / \mathrm{mL}$ & $4.85 \pm 1.9^{a}$ & $\begin{array}{l}5.86 \pm 1.06^{b} \\
(20.8 \%)\end{array}$ & $\begin{array}{l}6.34 \pm 1.25^{c} \\
(30.72 \%)\end{array}$ & $\begin{array}{l}6.29 \pm 1.12^{d} \\
(29.6 \%)\end{array}$ & $\begin{array}{l}\text { (a vs.b, a vs.c) } \\
P<0.01\end{array}$ \\
\hline $\mathrm{OC}, \mathrm{ng} / \mathrm{mL}$ & $9.09 \pm 2.6^{\mathrm{a}}$ & $10.07 \pm 1.89^{b}(10.78 \%)$ & $\begin{array}{l}10.98 \pm 1.65^{c} \\
(20.79 \%)\end{array}$ & $\begin{array}{l}10.66 \pm 1.56^{d} \\
(17.27 \%)\end{array}$ & $\begin{array}{l}\text { (a vs.b, a vs.c) } \\
P<0.01\end{array}$ \\
\hline BSAP, IU/L & $15.65 \pm 3.8^{\mathrm{a}}$ & $18.95 \pm 4.6^{\mathrm{b}}(21.08 \%)$ & $\begin{array}{l}17.89 \pm 3.98^{\mathrm{C}} \\
(14.4 \%)\end{array}$ & $\begin{array}{l}19.02 \pm 2.99^{d} \\
(15.65 \%)\end{array}$ & $\begin{array}{l}\text { (a vs.b, a vs.c) } \\
P<0.01\end{array}$ \\
\hline $\mathrm{CTX}, \mu \mathrm{g} / \mathrm{molCr}$ & $326 \pm 100^{a}$ & $826 \pm 189^{b}(153.3 \%)$ & $\begin{array}{l}988 . \pm 202^{c} \\
(203.1 \%)\end{array}$ & $\begin{array}{l}1062 \pm 246^{d} \\
(225.76 \%)\end{array}$ & $\begin{array}{l}\text { (a vs.b, a vs.c) } \\
P<0.0001\end{array}$ \\
\hline $\mathrm{DPD}, \mathrm{nmol} / \mathrm{molCr}$ & $2.89 \pm 0.8^{\mathrm{a}}$ & $5.82 \pm 1.3^{b}(101.3 \%)$ & $\begin{array}{l}6.06 \pm 1.9^{c} \\
(109.6 \%)\end{array}$ & $\begin{array}{l}6.92 \pm 1.7^{\mathrm{d}} \\
(139.4 \%)\end{array}$ & $\begin{array}{l}\text { (a vs.b, a vs.c) } \\
P<0.0001\end{array}$ \\
\hline $\mathrm{FSH}, \mathrm{mIU} / \mathrm{mgCr}$ & $21.89 \pm 4.8^{\mathrm{a}}$ & $57.6 \pm 5.8^{b}(163.13 \%)$ & $\begin{array}{l}58.3 \pm 6.2^{c} \\
(166.3 \%)\end{array}$ & $\begin{array}{l}60.2 \pm 5.2^{\mathrm{d}} \\
(175.0 \%)\end{array}$ & $\begin{array}{l}\text { (a vs.b, a vs.c) } \\
P<0.0001\end{array}$ \\
\hline $\mathrm{E} 1 \mathrm{G}, \mathrm{ng} / \mathrm{mgCr}$ & $46.73 \pm 7.3^{\mathrm{a}}$ & $186 . \pm 6.5^{b}(60.19)$ & $\begin{array}{l}13.8 \pm 0.4 .3^{c} \\
(70.3 \%)\end{array}$ & $\begin{array}{l}8.26 \pm 4.8^{\mathrm{d}} \\
(82.32 \%)\end{array}$ & $\begin{array}{l}\text { (a vs.b, a vs.c) } \\
P<0.0001\end{array}$ \\
\hline PTH, pg/mL & $27.19 \pm 3.6^{a}$ & $38.3 \pm 4.2^{b}(41.0 \%)$ & $37.8 \pm 3.6^{c}(39.17 \%)$ & $\begin{array}{l}37.6 \pm 3.6^{\mathrm{d}} \\
(38.43 \%)\end{array}$ & $\begin{array}{l}\text { a vs.b, a vs.c) } \\
\mathrm{P}<0.0001\end{array}$ \\
\hline BMD Spine, $\mathrm{g} / \mathrm{cm}^{2}$ & $1.096 \pm 0.138^{a}$ & $0.948 \pm 0.89 \mathrm{~b}(13.5 \%)$ & $\begin{array}{l}0.906 \pm 0.96^{c} \\
(17.3 \%)\end{array}$ & $\begin{array}{l}0.886 \pm 1.02^{d} \\
(19.2 \%)\end{array}$ & $\begin{array}{l}(\mathrm{a} v s . \mathrm{b}, \mathrm{a} v s . \mathrm{c}) \\
P<0.0001\end{array}$ \\
\hline BMD Hip, $\mathrm{g} / \mathrm{cm}^{2}$ & $0.983 \pm 0.146^{a}$ & $\begin{array}{l}0.836 \pm 0.92^{b} \\
(14.9 \%)\end{array}$ & $\begin{array}{l}0.764 \pm 0.99 \\
(21.70 \%)\end{array}$ & $\begin{array}{l}0.678 \pm 1.1 \\
(31.0)\end{array}$ & $\begin{array}{l}(\mathrm{a} v s . \mathrm{b}, \mathrm{a} v s . \mathrm{c}) \\
P<0.0001\end{array}$ \\
\hline
\end{tabular}

NS, Not significant

\section{Discussion}

This study has demonstrated changes in serum concentrations of the cytokines IL1 $\beta$, IL6, and TNF $\alpha$ in Indian women during menopausal transition. It is well known that cessation of ovarian function during menopause increases the rate of bone remodeling, resulting in accelerated bone loss. In addition to systemic hormones, changes in IL1 $\beta$, IL6, and TNF $\alpha$ during menopausal transition are also involved in the pathogenesis, development, and progression of postmenopausal osteoporosis and atherosclerosis (15). Earlier studies have reported that IL1 $\beta$, IL6, and TNF $\alpha$ act as bone-resorbing cytokines, whereas IL18 prevents bone resorption $(16,17)$. IL1 $\beta$, IL-4, IL-6, and TNF- $\alpha$ have been shown to be mediators of artherogenesis (18). IL1 $\beta$ levels, though slightly elevated in menopause, are not statistically significant $(19,20)$. Earlier studies have also reported that IL1 activity is increased in cultures and that IL1 mRNA levels rise in bone in estrogen-deficient humans, but the concentration of immunoreactive IL1 $\beta$ does not increase in circulation (21). Estrogen deficiency in menopause is also associated with increased production of IL-6, which stimulates bone resorption, but its role in human studies is controversial. Several studies have reported that there is no correlation between IL6 and bone mineral density in postmenopausal women $(22,23)$, whereas others have examined the cross-sectional rela- tionship of circulating levels of IL6 to BMD or markers of bone turnover in postmenopausal women, finding no significant association (24). In contrast, Pacifici et al. reported increased circulating levels of IL6 with high bone turnover in postmenopausal women. Elevated IL6 levels in our study corroborate the findings of Pacifici et al. (25). Most recently, Yasui et al. reported that serum IL-6 concentration during menopausal transition correlates negatively with serum estradiol concentration (26). A similar negative correlation of IL6 (103\% rise), with a rapid decline in estradiol glucuronide levels (70\%), during menopausal transition was observed in Indian women.

It is also well known that the accelerated phase of bone loss is limited to the first 5-10 years following menopause (27). This temporal limit in rapid bone loss after menopause appears to be closely related to temporal changes in cytokine activity. In the Heidelberg cohort of the EVOS study (28), the predictive effect of circulating IL-6 levels on postmenopausal femoral bone was limited to the first decade after menopause. In bone marrow cultures of early postmenopausal women, levels of IL-1, TNF $\alpha$, and IL- 6 were also high versus premenopausal women, but there was no difference in these cytokines between late postmenopausal women and premenopausal women, again suggesting that these cytokines increase solely in the first several years after menopause $(29,30)$. Our data show that IL6 is a major predictor 
of postmenopausal bone loss and that the effect appears to be more relevant in the first decade of menopause. Whether these findings reflect pathogenic differences between early and postmenopausal bone loss and whether serum IL6 also predicts fracture risk requires further elucidation.

Our demonstrates that cytokines and estrogen are associated with postmenopausal bone loss. Serum IL6 concentrations correlate negatively with E1G levels during menopausal transition. IL6, a potent bone-resorptive cytokine, can be used as a diagnostic marker with the bone resorption markers CTX, DPD, and E1G, which can aid in identifying women who are at risk for osteoporosis and predicting bone loss in menopausal women.

\section{Acknowledgement}

The authors wish to thank the participants of the study. We are grateful to Director S.D. Kholkute for their encouragement during the course of the study. We thank the Department Of Family Welfare, Govt. of India for providing the financial support for the study. Our sincere thanks are also due to Dr. J. Chaphekar, Streehitakarini Clinic staff for assisting in the enrollment of the participants without their support this study would not have been possible.

\section{Financial Disclosure}

None declared.

\section{Funding/Support}

None declared.

\section{References}

1. Cioffi M, Esposito K, Vietri MT, Gazzerro P, D’Auria A, Ardovino I, et al. Cytokine pattern in postmenopause. Maturitas. 2002;41 (3) :187-92.

2. Kamada M, Irahara M, Maegawa M, Ohmoto Y, Takeji T, Yasui T, et al. Postmenopausal changes in serum cytokine levels and hormone replacement therapy. Am J Obstet Gynecol. 2001;184 (3) :309-14.

3. Kumru S, Godekmerdan A, Yilmaz B. Immune effects of surgical menopause and estrogen replacement therapy in peri-menopausal women. J Reprod Immunol. 2004;63 (1) :31-8.

4. Jilka RL, Hangoc G, Girasole G, Passeri G, Williams DC, Abrams JS, et al. Increased osteoclast development after estrogen loss: mediation by interleukin-6. Science. 1992;257 (5066):88-91.

5. Pacifici R. Estrogen, cytokines, and pathogenesis of postmenopausal osteoporosis. J Bone Miner Res. 1996;11 (8) :1043-51.

6. Prince RL. Counterpoint: estrogen effects on calcitropic hormones and calcium homeostasis. Endocr Rev. 1994;15 (3) :301-9.

7. Lorentz K. Improved determination of serum calcium with 2-cresolphthalein complexone. Clin Chim Acta. 1982;126 (3) :327-34.

8. Gomorri GA. Modification of calorimetric phosphorous determination for use with photoelectric calorimeter. J lab Clin Med. 1942;27:955-60.

9. Desai M, Khatkhatay I, Sankolli G, Meherji P, Joshi U. Enzyme-labelled immunoassay for urinary gonadotropins using penicillinase. Clin Chim Acta. 1989;184 (3) :315-21.

10. Khatkhatay MI, Sankolli GM, Meherji PK, Chowdhury V, Joshi UM. Excretion of estrone-3-glucuronide in urine in spontaneous and induced ovulatory cycles. Int J Fertil. 1988;33 (3) :181-7.

11. Jaffe M. Uberden Niederschlag Welchen Pickrinasure in normalem Harn erzengl and uberein nene Reaklion des Kreatinine Z. Physiol Chem.1886;10:391-4.
12. WHO. Technical Reports Series 843 Assessment of fracture risk and its application to screening for postmenopausal osteoporosis Geneva; 1994 [updated 1994; cited]; Available from: http:// www.who.int/entity/chp/topics/Osteoporosis.pdf.

13. Desai Meena P, Khatkhatay MI, Bhanu Prakash KV, Savardekar LS, Shah RS, Ansari Z. Hormonal profiles and biochemical indices of bone turnover in Indian women. Osteoporos Int. 2007;18 (7) :923-9.

14. Desai MP, Bhanuprakash KV, Khatkhatay MI, Donde UM. Age-related changes in bone turnover markers and ovarian hormones in premenopausal and postmenopausal Indian women. J Clin Lab Anal. 2007;21 (2) :55-60.

15. Romas E, Martin TJ. Cytokines in the pathogenesis of osteoporosis. Osteoporos Int. 1997;7 (Suppl 3) :S47-53.

16. Berg G, Ekerfelt C, Hammar M, Lindgren R, Matthiesen L, Ernerudh J. Cytokine changes in postmenopausal women treated with estrogens: a placebo-controlled study. Am J Reprod Immunol. 2002;48 (2) :63-9.

17. Horwood NJ, Udagawa N, Elliott J, Grail D, Okamura H, Kurimoto $\mathrm{M}$, et al. Interleukin 18 inhibits osteoclast formation via $\mathrm{T}$ cell production of granulocyte macrophage colony-stimulating factor. J Clin Invest. 1998;101 (3) :595-603.

18. de Bont N, Netea MG, Rovers C, Smilde T, Demacker PN, van der Meer JW, et al. LPS-induced cytokine production and expression of LPS-receptors by peripheral blood mononuclear cells of patients with familial hypercholesterolemia and the effect of HMG-CoA reductase inhibitors. Atherosclerosis. 1998;139 (1) :147-52.

19. Barks JL, McQuillan JJ, Iademarco MF. TNF-alpha and IL-4 synergistically increase vascular cell adhesion molecule-1 expression in cultured vascular smooth muscle cells. J Immunol. 1997;159 (9) :4532-8.

20. Fagiolo U, Cossarizza A, Scala E, Fanales-Belasio E, Ortolani C, Cozzi E, et al. Increased cytokine production in mononuclear cells of healthy elderly people. Eur J Immunol. 1993;23 (9) :2375-8.

21. Khosla S, Peterson JM, Egan K, Jones JD, Riggs BL. Circulating cytokine levels in osteoporotic and normal women.J Clin Endocrinol Metab. 1994;79 (3) :707-11.

22. Daynes RA, Araneo BA, Ershler WB, Maloney C, Li GZ, Ryu SY. Altered regulation of IL-6 production with normal aging. Possible linkage to the age-associated decline in dehydroepiandrosterone and its sulfated derivative. J Immunol. 1993;150 (12) :521930.

23. Papadopoulos NG, Georganas K, Skoutellas V, Konstantellos E, Lyritis GP. Correlation of interleukin-6 serum levels with bone density in postmenopausal women. Clin Rheumatol. 1997;16 (2) :162-5.

24. Kania DM, Binkley N, Checovich M, Havighurst T, Schilling M, Ershler WB. Elevated plasma levels of interleukin-6 in postmenopausal women do not correlate with bone density. J Am Geriatr Soc. 1995;43 (3) :236-9.

25. Pacifici R, Brown C, Puscheck E, Friedrich E, Slatopolsky E, Maggio $\mathrm{D}$, et al. Effect of surgical menopause and estrogen replacement on cytokine release from human blood mononuclear cells. Proc Natl Acad Sci U S A. 1991;88 (12): 5134-8.

26. Yasui T, Maegawa M, Tomita J, Miyatani Y, Yamada M, Uemura H, et al. Changes in serum cytokine concentrations during the menopausal transition. Maturitas. 2007;56 (4):396-403.

27. Scheidt-Nave CE, Bismar H, G. L-B, Seibel MJ, Ziegler R, Pfeilschifter J. Serum interleukin-6 is a major predictor of bone loss in women specific to the first decade past menopause. 1997 (Suppl 147).

28. Abrahamsen B, Bonnevie-Nielsen V, Ebbesen EN, Gram J, BeckNielsen H. Cytokines and bone loss in a 5-year longitudinal study--hormone replacement therapy suppresses serum soluble interleukin-6 receptor and increases interleukin-1-receptor antagonist: the Danish Osteoporosis Prevention Study. J Bone Miner Res. 2000;15 (8) :1545-54.

29. Ershler WB. Interleukin-6: a cytokine for gerontologists. J Am Geriatr Soc. 1993;41 (2):176-81.

30. Lutgendorf SK, Garand L, Buckwalter KC, Reimer TT, Hong SY, Lubaroff DM. Life stress, mood disturbance, and elevated interleukin-6 in healthy older women. J Gerontol A Biol Sci Med Sci. 1999;54 (9) :M434-9. 